\title{
DIAGNÓSTICO CLÍNICO, LABORATORIAL E NECROSCÓPICO DA PERITONITE INFECCIOSA FELINA: RELATO DE CASO
}

\author{
(Clinical, laboratory and necroscopic diagnosis of feline infectious peritonitis: case report) \\ ${ }^{1}$ Nathalia Tianny Gonçalves, ${ }^{1}$ Sabrina Nascimento Ferreira, ${ }^{1}$ Guilherme Dallazen Aguiar, ${ }^{2}$ Carina De Fátima \\ Guimarães Dallazen
}
${ }^{1}$ Centro de Ensino Superior dos Campos Gerais - CESCAGE, Brasil. ${ }^{2}$ Docente curso de Medicina Veterinária no Centro Universitário de Maringá - UNICESUMAR, Brasil.

\section{*Correspondência: nathaliatgoncalves@hotmail.com}

Resumo: Foi atendida em um centro veterinário particular na cidade de Ponta Grossa, estado do Paraná, uma paciente felina, da raça Persa, com oito meses de idade e pesando $1,9 \mathrm{~kg}$, com histórico de perda de peso, inapetência e diarreia esporádica. Ao exame físico apresentou mucosas normocoradas, desidratação, secreção ocular discreta e leve dor abdominal à palpação. Foram solicitados exames complementares para delinear o diagnóstico. As principais alterações ultrassonográficas foram dilatação de vasculatura hepática, dilatação de pelve renal esquerda, enterite difusa, mesentério com intenso sinal positivo ao doppler e presença de líquido livre abdominal. No hemograma observou-se microcitose, hipoproteinemia, linfopenia, desvio nuclear de neutrófilos a esquerda degenerativo, trombocitose e anisocitose plaquetária. Nos exames bioquímicos as alterações foram hipercolesterolemia e hiperglicemia. A coleta de urina foi realizada por cistocentese, e, após análise, a urina apresentou densidade aumentada, uma cruz de proteínas presentes, leucocitose, presença de hemácias e células epiteliais, sem bactérias sensíveis ao Gram. O resultado do teste SNAP para FIV e FeLV (IDEXX®) foi negativo para ambas as doenças. Procedeu-se com a coleta e análise do líquido ascítico, o líquido ao exame físico era de coloração amarelo palha, com pH aumentado $(8,0)$, aumento das proteínas totais e da glicose, na contagem total de células verificou-se a presença de células nucleadas acima da referência descrita, sem bactérias sensíveis ao Gram. Após a análise da efusão, devido à coloração amarelo-palha ser característica da peritonite infecciosa felina (PIF) (KENNEDY; LITTLE, 2016), procedeu-se com a coleta hematológica para realizar o PCR (reação em cadeia da polimerase) para a PIF. A paciente foi internada para tratamento de suporte, correção da desidratação e manejo alimentar. Instituiu-se fluidoterapia considerando $8 \%$ de desidratação, alimentação com alimento hipercalórico (Nutralife $\left.{ }^{\circledR}\right)$ via seringa, administração de dipirona 25 $\mathrm{mg} / \mathrm{kg}$ a cada oito horas, omeprazol $1 \mathrm{mg} / \mathrm{kg}$ a cada 12 horas, citrato de maropitant (Cerenia $($ ) $1 \mathrm{mg} / \mathrm{kg}$ a cada 24 horas e suplemento vitamínico (Bionew ${ }^{\circledR}$ ) $0,2 \mathrm{~mL} / \mathrm{kg}$ a cada 24 horas. Durante o primeiro dia de internação, a paciente permaneceu apática, com parâmetros vitais dentro da normalidade, não aceitando alimentação espontaneamente e, a partir do segundo dia, além dos sinais descritos, apresentou hipotermia e hipoglicemia, a segunda corrigida com a administração de glicose endovenosa, no entanto ainda no segundo dia de internação a paciente entrou em óbito. Para concluir o diagnóstico, devido à espera do resultado do exame de PCR, solicitou-se a realização de exame necroscópico. O laudo constatou, como principal alteração, lesão vascular (arterite) observada em vários órgãos, levando, devido à ausência de integridade do endotélio vascular, ao extravasamento de líquido do meio intravascular para o extravascular, causando grave choque hipovolêmico, insuficiência cardiorrespiratória e óbito. As causas infecciosas para arterite relatadas em felinos são os fungos, não sendo observadas estruturas fúngicas à microscopia neste caso, e as infecções por coronavírus felino (FCoV), como a PIF (JONES; HUNT; KING, 2000). O resultado do PCR, feito com amostra de sangue total, foi positivo para o vírus da PIF.

Palavras-chave: PIF; coronavírus felino; arterite; PCR

\section{Referências}


JONES, T. C.; HUNT, R. D.; KING, N. W. Patologia veterinária. 6 ed. Barueri: Manole, 2000. p. 362-363.

KENNEDY, M.; LITTLE, S.E. Doenças Virais. Em: LITTLE, S.E. O gato: medicina interna. 1 ed. Rio de Janeiro: Roca, 2015. p. 999-1007. 